Article

\title{
Cathodic Protection Using Aluminum Metal in Chloride Molten Salts as Thermal Energy Storage Material in Concentrating Solar Power Plants
}

\author{
Angel G. Fernández * and Luisa F. Cabeza \\ GREiA Research Group, Universitat de Lleida, Pere de Cabrera s/n, 25001 Lleida, Spain; luisaf.cabeza@udl.cat \\ * Correspondence: angel.fernandez@udl.cat; Tel.: +34-973-003515
}

Received: 5 May 2020; Accepted: 25 May 2020; Published: 27 May 2020

check for updates

Featured Application: Concentrated solar power technology, corrosion mitigation strategy on TES materials at high temperature.

\begin{abstract}
The new generation of concentrated solar power (CSP) plants to be developed presents a great challenge related to the increase in maximum operating temperature since molten salt CSP technologies require alternative salt chemistries such as chloride. The cathodic protection strategy involves the addition of a sacrificial metal to prevent corrosion of the alloy tested as container material in a CSP plant. In this paper, aluminum (Al) metal was analyzed as a corrosion inhibitor in OCT and HR224 alloys, obtaining corrosion rates of 4.37 and $0.27 \mathrm{~mm} / \mathrm{y}$, respectively. It has been confirmed that the use of $\mathrm{Al}$ metal can reduce the anodic current which is directly related to the corrosion rate. The formation of protective alumina scales $\left(\mathrm{Al}_{2} \mathrm{O}_{3}\right)$ was assessed by scanning electron microscopy (SEM) and X-ray diffraction (XRD), confirming the corrosion model results from electrochemical impedance spectroscopy monitoring tests.
\end{abstract}

Keywords: thermal energy storage (TES); concentrated solar power (CSP); corrosion mitigation; chloride molten salt; cathodic protection

\section{Introduction}

In the last years, an opportunity has been identified to obtain higher power-generation efficiencies in concentrated solar power (CSP) plants using supercritical $\mathrm{CO}_{2}\left(\mathrm{sCO}_{2}\right)$ Brayton power cycle. The CSP technology needs to integrate high-temperature storage materials able to work in the range of $550{ }^{\circ} \mathrm{C}$ to $750{ }^{\circ} \mathrm{C}$ [1]. For this purpose, the selection of high-temperature molten salt chemistry is needed and due to their low cost and high decomposition temperature, molten chlorides have been proposed as a feasible option. However, these molten salts introduce important drawbacks related to their very corrosive nature on typical containment materials.

According to Mehos et al. [1], the cost for the chloride salt system is dominated by the cost of the material to contain the storage material hot salt tank (70\%) due to the expense and size of this tank. In this case, the cold tank would be built using austenitic stainless steel since the operating temperature for this tank would be $520^{\circ} \mathrm{C}$. This cost simulation was carried out using Haynes 230 alloy in the hot tank and AISI 347 in the cold storage tank.

It is clear that a corrosion mitigation strategy is necessary to use low-cost alloys in the CSP storage tanks. With this aim, cathodic protection has been proposed in the literature [2,3] to mitigate corrosion of alloys in molten salts, using a sacrificial metal that more easily "corrodes" is used to prevent corrosion of the alloy or its components. It was shown that the major corrosion mechanism of alloys in molten salts is the selective oxidation of chromium [4]. It usually occurs at the 
grain boundaries $[5,6]$. Such experimental observation is confirmed by electrochemical impedance spectroscopy (EIS) measurement showing a phase angle no higher than $45^{\circ} \mathrm{C}$ which indicates that the corrosion of alloys in molten salts has fast reaction kinetics and it is usually mass-transfer limited. It was shown that $\mathrm{Cr}^{3+}$ is less thermodynamically stable than the cations in the molten $\mathrm{MgCl}_{2}-\mathrm{KCl}$ mixture (i.e., $\mathrm{Mg}^{2+}$ and $\mathrm{K}^{+}$) such that $\mathrm{Cr}$ in the alloy will not react with $\mathrm{Mg}^{2+}$ and/or $\mathrm{K}^{+}$to form $\mathrm{Cr}^{3+}[7,8]$. However, $\mathrm{Cr}^{2+}$ is more thermodynamically stable, which means that $\mathrm{Cr}$ in the alloy tends to react, forming $\mathrm{Cr}^{2+}$. The oxidation of $\mathrm{Cr}$ to form $\mathrm{Cr}^{2+}$ accounts for the major corrosion mechanism of Cr-containing alloys.

In this case, some authors [2,9] have proposed the addition of $\mathrm{Mg}$ metal into the chloride molten salt mixture, since the reduction potential of the alloy components can be modified, obtaining that the main anodic current belongs to the oxidation of this metal, avoiding the oxidation of the target alloy.

The corrosion rates of Haynes 230, Haynes 163, and Incoloy 800H were experimentally obtained as a function of wt. $\%$ of $\mathrm{Mg}$ added (from $0 \%$ to $1.15 \%$ ). In all three cases, the corrosion rates were significantly reduced and the results from experiments and modeling agreed very well. Specifically, the corrosion rate of Haynes 230 at $850^{\circ} \mathrm{C}$ was reduced to less than $15 \mu \mathrm{m} / \mathrm{y}$ with $1.15 \mathrm{wt} . \% \mathrm{Mg}$ addition compared to the baseline test without $\mathrm{Mg}$ addition. A key effect of this behavior is the formation of magnesium oxide $(\mathrm{MgO})$ on the cathode, which can be related to the electrode passivation, obtaining a lower electrolysis current [2].

Corrosion products formed in $\mathrm{Mg}$ metal can introduce a new set of impurities in the molten salt, affecting the thermal properties of this material so the proposal of new cathodic elements needs to be addressed.

In this research, a first approach of a new cathodic element ( $\mathrm{Al}$ metal) is proposed in order to mitigate corrosion. Al metal presents a reduction potential voltage $\left(\mathrm{Al} \rightarrow \mathrm{Al}^{3+}\right)$ of $-1.662 \mathrm{~V}$, acting as an anode in contact with the common elements present in superalloys $\mathrm{Ni} \rightarrow \mathrm{Ni}^{2+}(1.59 \mathrm{~V})$ or $\mathrm{Cr} \rightarrow \mathrm{Cr}^{2+}$ $(1.33 \mathrm{~V})$. This element can also reduce the impurities formed in the chloride salts and maintain the thermal properties required for TES materials with a lower corrosion rate potential.

\section{Methodology}

A ternary chloride molten salt composed of 20.4 wt. $\% \mathrm{KCl}+55.1 \mathrm{wt} . \% \mathrm{MgCl}_{2}+24.5 \mathrm{wt} . \% \mathrm{NaCl}$ (Sigma Aldrich 99\%, Missouri, USA) was selected as thermal energy storage material. Experimental tests were carried out at $720^{\circ} \mathrm{C}$ under inert atmosphere $\left(\mathrm{N}_{2}\right)$.

The salts were dried and purified following stepwise heating for the purification process, previously reported in [10], was carried out. After this process, the electrodes were immersed in the chloride salt at $720{ }^{\circ} \mathrm{C}$, including $10 \mathrm{wt} . \% \mathrm{Al}$ metal (100\% bare $\mathrm{Al}$ metal, Randrade, Spain).

The electrochemical impedance spectroscopy (EIS) cell was composed of a working electrode (WE, with the alloy to be tested), a quasi-reference (RE, platinum wire), and a counter (CE, platinum mesh) electrode. For the corrosion test, the electrodes were introduced in the molten salt, acting as electrolyte, and the electrochemical parameters were measured using the EIS equipment (Gamry 1010E, Gamry, Philadelphia, PA, USA). The experimental set up is shown in Figure 1.

EIS tests were carried out at 3,5,24, and $50 \mathrm{~h}$ of immersion in order to monitor the corrosion mechanism and the frequency range for EIS tests was between $10^{5}$ and $0.01 \mathrm{~Hz}$. Finally, linear polarization resistance (LPR) tests were performed from a potential of -0.6 to $0.4 \mathrm{~V}$ were carried out in two different alloys, with a chemical composition shown in Table 1. 


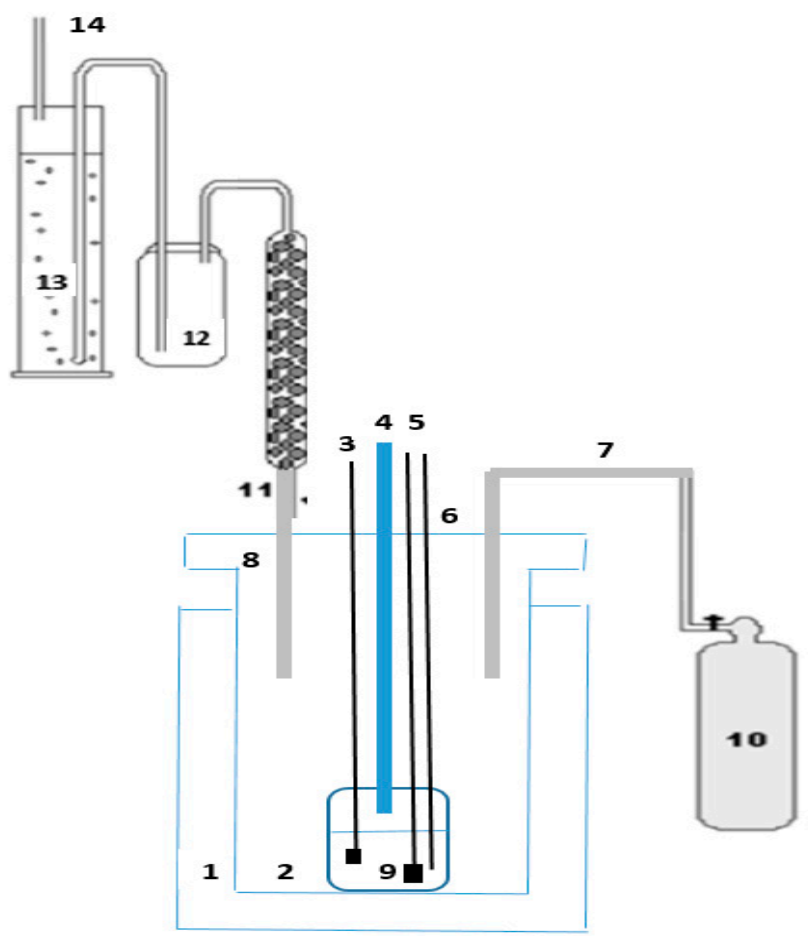

Figure 1. Electrochemical impedance spectroscopy (EIS) experimental setup test: 1: furnace; 2: reactor; 3: counter electrode, 4: thermocouple, 5: working electrode, 6: quasi-reference electrode, 7: gas inlet, 8: sealed reactor, 9: molten salt, 10: carrier gas $\left(\mathrm{N}_{2}\right), 11: \mathrm{MgO}$ trap; 12: security trap; 13: $\mathrm{NaOH}$ [1M] and 14: gas outlet.

Table 1. Chemical composition of alloys tested.

\begin{tabular}{cccccccccc}
\hline \multirow{2}{*}{ Alloys } & \multicolumn{10}{c}{ wt. $\%$} \\
\cline { 2 - 10 } & $\mathrm{Nb}$ & $\mathrm{Mn}$ & $\mathrm{Cr}$ & $\mathrm{Ti}$ & $\mathrm{Co}$ & $\mathrm{Mo}$ & $\mathrm{Ni}$ & $\mathrm{Al}$ & Fe \\
\hline OCT & 3 & - & 14 & 2 & - & - & 35 & 3 & Balance \\
\hline HR224 & - & 0.5 & 20 & 0.3 & 2 & 0.5 & 47 & 3.8 & 27.5 \\
\hline
\end{tabular}

After the corrosion tests, the samples were cleaned with hot distilled water and dried. For SEM characterization, a polymer resin was prepared by mixing HardRock 554 resin (Phase, Firenze, Italy) and catalyst, in a 2:1 proportion. After the resin cured, the samples were ground and polished using different granulometry of $\mathrm{SiC}$ abrasive papers, using diamond power (1 micron) to polish the samples. Quanta 200 FEG SEM operated in high vacuum mode at $20 \mathrm{kV}$ equipped with a backscattered electron detector was used for the microstructural analysis, including an EDX analyzer with a recommended working distance of around $10 \mathrm{~mm}$.

For XRD tests, a PANalytical X'Pert PRO powder diffractometer (Perkin-Elmer, Waltham, MA, USA) was used with a $\theta / 2 \theta$ incidence from 10 to $100^{\circ}$.

Using electrochemical impedance spectroscopy (EIS), different authors [11-13] have proposed equivalent circuits corresponding to the main corrosion mechanisms in molten salts at high temperatures, obtaining protective, porous, or localized corrosion models.

For linear polarization resistance tests, it is important to quantify the polarization resistance, $R_{p}$, related to the potential drop attributed to the molten salt, acting as electrolyte. The corrosion density current $\left(i_{\text {corr }}\right)$ can be obtained using Equation (1):

$$
i_{\text {corr }}=\frac{B}{R_{p}}
$$


where $B$ is an electrochemical constant calculated through the anodic and cathodic Tafel slopes by Equation (2):

$$
B=\frac{\beta_{\alpha} \cdot \beta_{c}}{2.3 \cdot\left(\beta_{\alpha}+\beta_{c}\right)}
$$

The corrosion rate (CR) is given by the Butler-Volmer equation shown in Equation (3)

$$
C R=\frac{i_{\text {corr }} \cdot K}{\rho_{\text {alloy }} \cdot \Sigma\left(\frac{f_{i} \cdot n_{i}}{M W_{i}}\right)}
$$

where $K$ is a constant with a value of 3272 for $C R$ in $\mathrm{mm} / \mathrm{y}, \rho_{\text {alloy }}$ is the alloy density $\left(\mathrm{g} / \mathrm{cm}^{3}\right), f_{i}$ is the mole fraction of the element $i$ in the alloy, $n_{i}$ is the number of electrons that are transferred in the corrosion process, and $M W_{i}$ is the atomic weight of the alloy tested.

\section{Results and Discussion}

EIS signals (Nyquist plots) obtained for OCT alloy (Figure 2) were fitted to a protective layer model during the corrosion process at the different testing times. The equivalent circuit element values for this material are shown in Table 2.

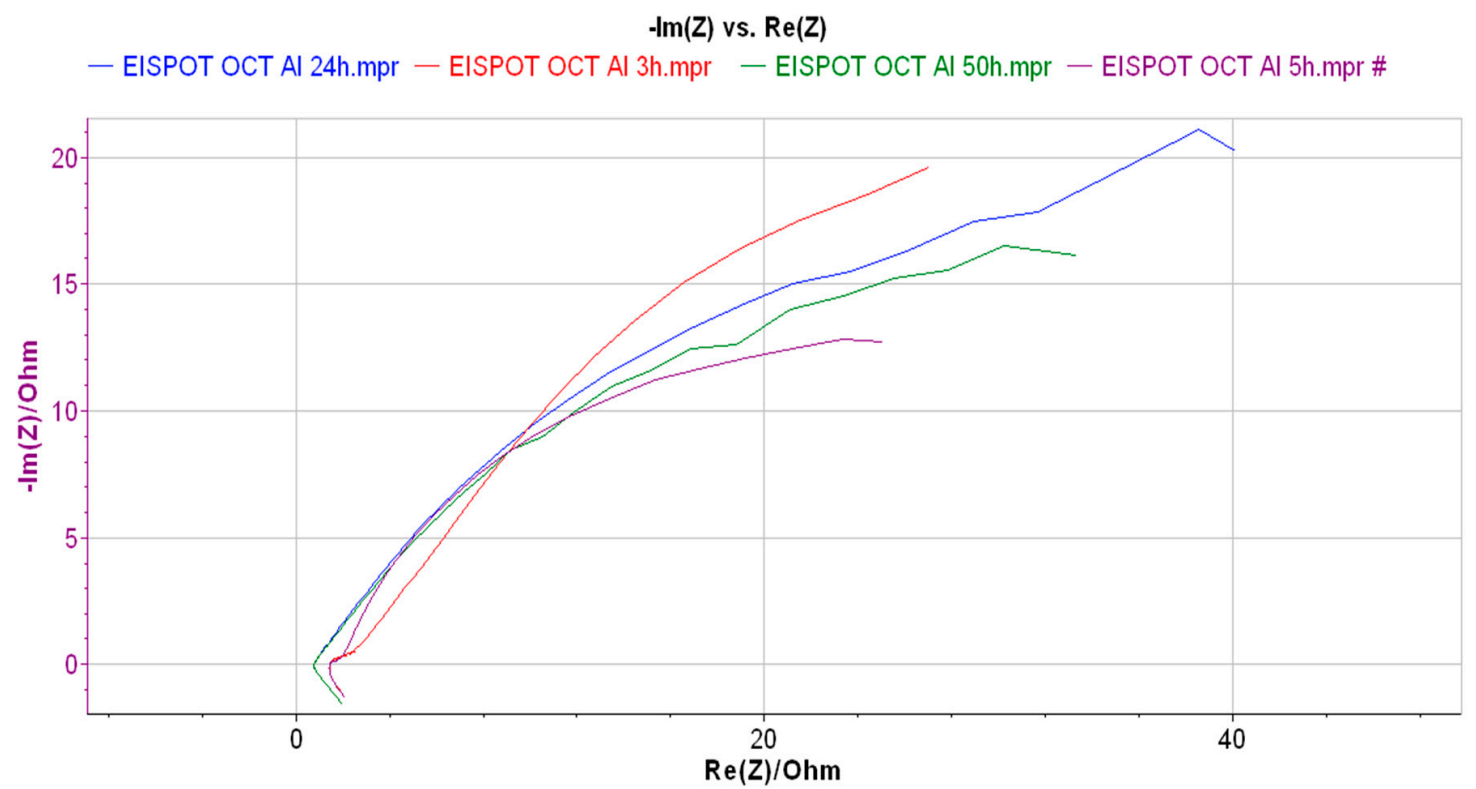

Figure 2. Nyquist plots of OCT immersed chloride molten salt at 3, 5, 24, and $50 \mathrm{~h}$.

Table 2. Electrochemical parameters obtained for electrochemical impedance spectroscopy (EIS) tests in OCT alloy.

\begin{tabular}{cccccccc}
\hline Element & $\begin{array}{c}\mathbf{R 3} \\
(\mathbf{O h m})\end{array}$ & $\begin{array}{c}\mathbf{Q 1} \\
\mathbf{( F / s )}\end{array}$ & $\begin{array}{c}\mathbf{R 5} \\
(\mathbf{O h m})\end{array}$ & $\begin{array}{c}\mathbf{Q} 2 \\
\mathbf{( F / s )}\end{array}$ & $\begin{array}{c}\mathbf{R 7} \\
(\mathbf{O h m})\end{array}$ \\
\hline $3 \mathrm{~h}$ & 1.507 & 0.325 & 36.21 & 0.183 & 59.45 & & Equivalent Circuit \\
$5 \mathrm{~h}$ & 1.561 & 0.243 & 15.56 & 0.289 & 232.07 \\
$50 \mathrm{~h}$ & 0.853 & 0.007 & 0.06 & 0.056 & 63.56 \\
\hline
\end{tabular}

$R_{3}$ represents the molten salt (electrolyte) resistance and $R_{5}$ is the electrochemical transfer resistance or polarization resistance of the tested material. $Q_{1}$ is the double layer at the metal/salt interface and $Q_{2}$ represents the oxide capacitance. The $R_{7}$ electrochemical parameter is related to the transfer resistance of ions in the scale. In this case, it is important to point out that the electrolyte resistance (R3) 
decreases during the experimental time, so electronic conductivity may be favored as well as corrosion potential processes.

These results were confirmed by SEM analysis (Figure 3), obtaining a protective layer with $\mathrm{Fe}-\mathrm{Cr}-\mathrm{Ni}-\mathrm{Al}-\mathrm{O}$ content.

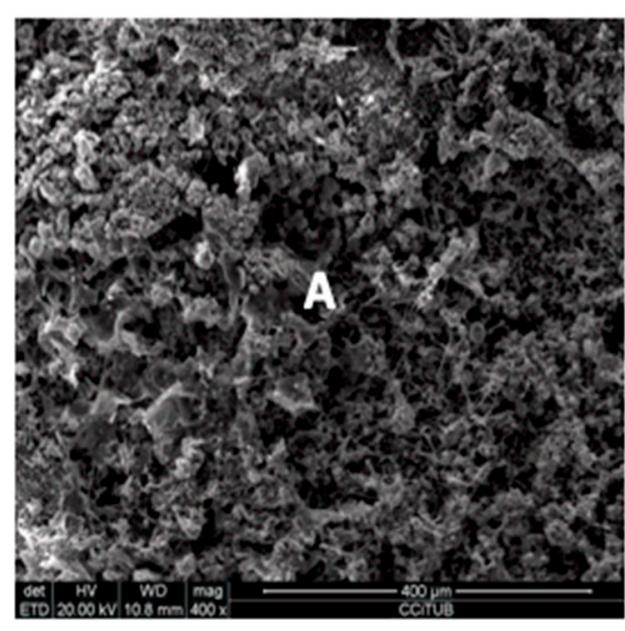

\begin{tabular}{|c|c|c|c|c|c|c|}
\hline $\begin{array}{l}\text { Element. } \\
(w t . \%) \text { x }\end{array}$ & Fex & Cra & $\mathrm{Ni}$ & $\mathbf{M g} \propto$ & $\mathrm{O} \alpha$ & Ala \\
\hline$A x$ & $38.45 x$ & $12.21 x$ & $24.95 x$ & $2.34 \alpha$ & $3.67 x$ & $1.86 x$ \\
\hline$B \alpha$ & $16.32 \alpha$ & $1.37 a$ & 18.71ø & $7.55 \alpha$ & 8.08 a & $5.67 \alpha$ \\
\hline
\end{tabular}

Figure 3. Top view (left) and cross-section; (right) images for OCT immersed in chloride molten salt for $50 \mathrm{~h}$ at $720^{\circ} \mathrm{C}$ including energy dispersive X-ray (EDX) analysis (A-B).

OCT alloy was previously tested [14] for $8 \mathrm{~h}$ of immersion in the same chloride molten salt. In this case, no internal oxidation was detected after $50 \mathrm{~h}$ using $\mathrm{Al}$ metal as cathodic protection.

Results obtained for HR224 alloy (Figure 4) were fitted to a protective corrosion model during all the testing times. Electrochemical parameters obtained for the equivalent circuits are shown in Table 3.

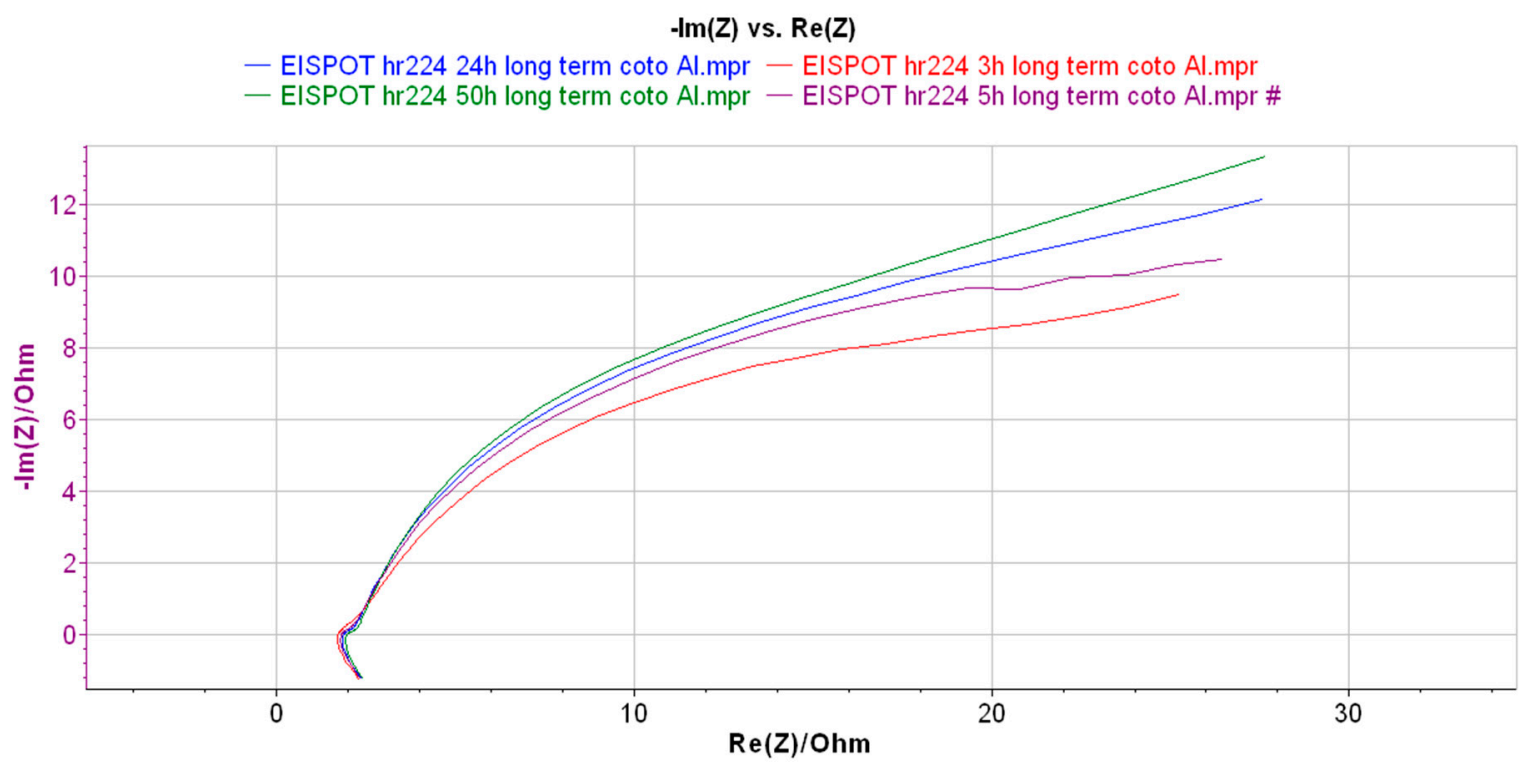

Figure 4. Nyquist plots of HR224 immersed in chloride molten salt at 3, 5, 24, and $50 \mathrm{~h}$. 
Table 3. Electrochemical parameters obtained for EIS tests in HR224 alloy.

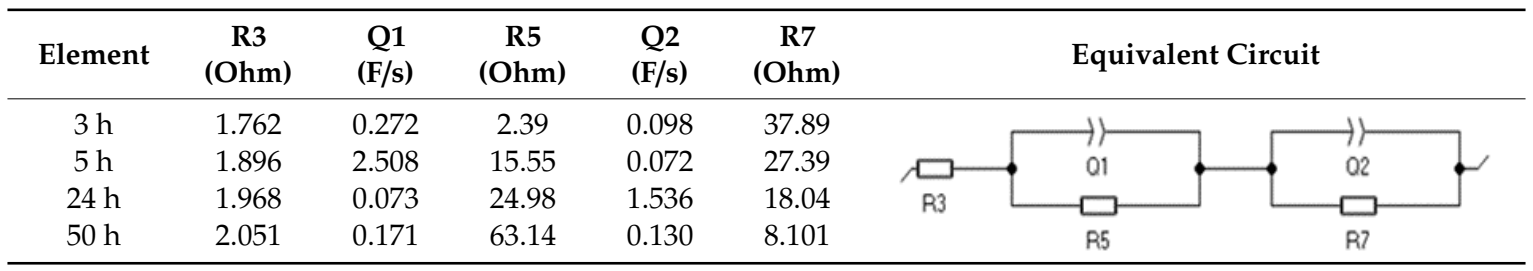

SEM analysis (Figure 5) showed internal oxidation of 28.35 microns of thickness (Figure 5 right) with higher Ni content. This internal oxidation was reported [15] as a potential problem since it can cause mechanical failures during thermal cycles in the CSP plant operation.
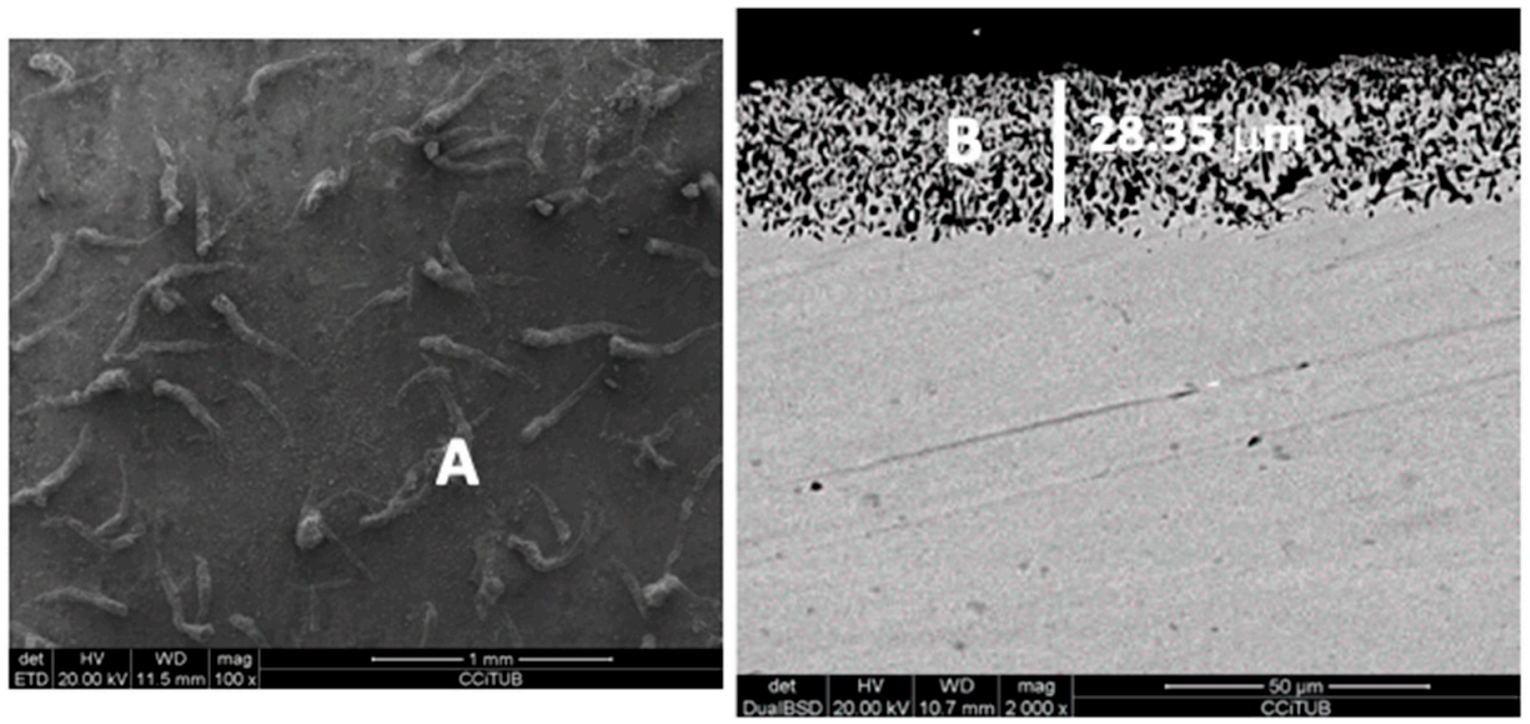

\begin{tabular}{|c|c|c|c|c|c|c|}
\hline $\begin{array}{l}\text { Element } \\
(w t . \%) \times\end{array}$ & Fex & Crox & Nix & $\operatorname{Mg} \propto$ & $\mathrm{O}_{\alpha}$ & Alx \\
\hline$A x$ & $28.65 x$ & 21.81x & $47.72 \propto$ & $-\infty$ & $0.41 x$ & $1.41 \not$ \\
\hline$B a$ & $22.17 x$ & $5.10 \propto$ & $62.99 x$ & $1.45 \propto$ & $2.39 x$ & $5.90 x$ \\
\hline
\end{tabular}

Figure 5. Top view (left) and cross-section; (right) images for HR224 alloy immersed in chloride molten salt for $50 \mathrm{~h}$ at $720^{\circ} \mathrm{C}$ including EDX analysis (A-B).

The superficial image (Figure 5 left) showed some needle-shaped particles in the alloy surface, with content in aluminum. Similar particles were obtained by Fernandez et al. [16] adding $\mathrm{Al}_{2} \mathrm{O}_{3}$ nanoparticles in nitrate molten salts, reporting a higher corrosion resistance behavior due to this protective barrier formed in the alloy/salt interphase.

In order to confirm the corrosion layer composition obtained, XRD analysis was carried out in the materials tested. Protective layers composed of $\mathrm{Al}_{2} \mathrm{O}_{3}$ and $\mathrm{NiO}$ were obtained for $\mathrm{HR} 224$ (Figure 6) and $\mathrm{Al}_{2} \mathrm{O}_{3}$ for OCT (Figure 7), confirming the protective mechanism detected by EIS and SEM. 


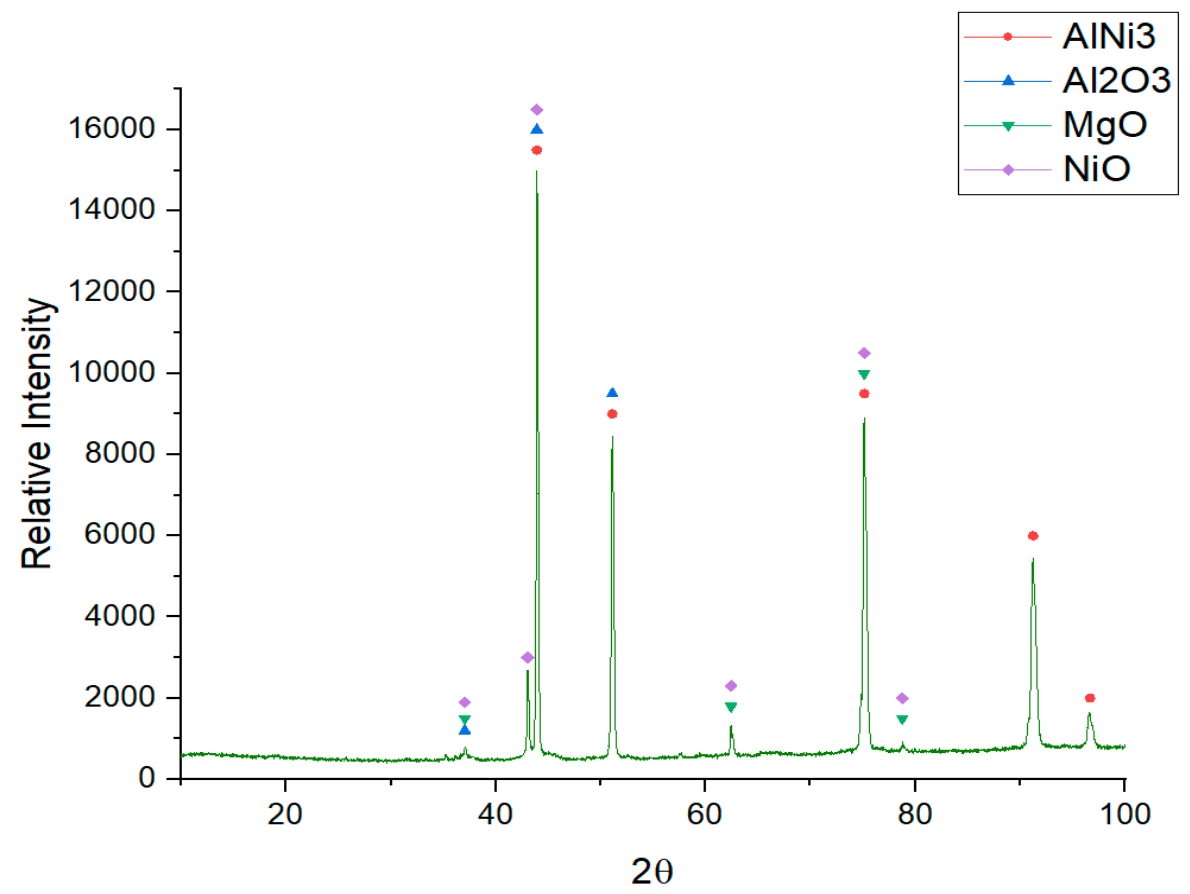

Figure 6. X-ray diffraction (XRD) obtained in HR224 after $50 \mathrm{~h}$ of immersion in chloride molten salt at $720^{\circ} \mathrm{C}$.

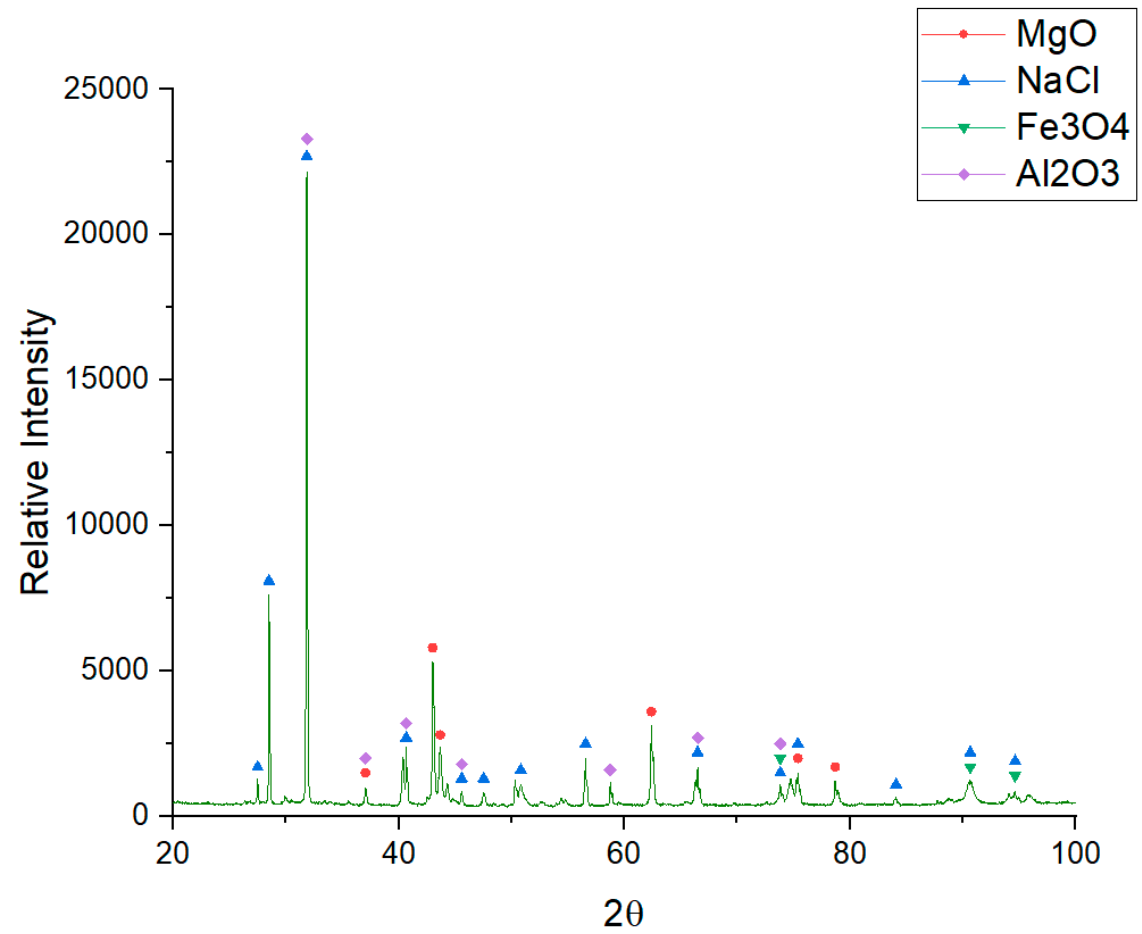

Figure 7. XRD obtained in OCT after $50 \mathrm{~h}$ of immersion in chloride molten salt at $720^{\circ} \mathrm{C}$.

Additionally, slight signals corresponding to $\mathrm{Fe}_{3} \mathrm{O}_{4}$ were detected in OCT alloy. Another impurity detected in both alloys was $\mathrm{MgO}$. This impurity must be controlled during the corrosion process since it can form $\mathrm{MgClOH}$, one of the most aggressive impurities present in the chloride molten salt tested $[17,18]$. In this direction, some researchers $[19,20]$ have applied cyclic voltammetry tests to monitor impurities production as well as to define more specific thermal purification analysis during the melting process to control the evolution of this impurity during the corrosion process. 
Corrosion rate results obtained through linear polarization technique after $50 \mathrm{~h}$ of immersion are shown in Table 4.

Table 4. Electrochemical parameters and corrosion rates obtained and linear polarization resistance (LPR) test for OCT and HR224 alloys.

\begin{tabular}{ccccccc}
\hline Alloys & Ecorr $(\mathbf{m V})$ & Icorr $(\mathbf{m A})$ & $\beta \mathbf{c}(\mathbf{m V})$ & $\beta \mathbf{a}(\mathbf{m V})$ & $\mathbf{A}\left(\mathbf{c m}^{2}\right)$ & $\mathbf{C R}(\mathbf{m m} / \mathbf{y})$ \\
\hline OCT & -87.32 & 2098.62 & 280.8 & 465.6 & 4.20 & 4.37 \\
HR224 & -31.16 & 210.62 & 239.7 & 241.3 & 6.75 & 0.27 \\
\hline
\end{tabular}

As it was mentioned before, these materials were studied for $8 \mathrm{~h}$ of immersion in previous research [15], obtaining a corrosion rate of $7.61 \mathrm{~mm} / \mathrm{y}$ for OCT alloy and $3.12 \mathrm{~mm} / \mathrm{y}$ for HR224. In this case, corrosion rates obtained using $\mathrm{Al}$ metal as a cathodic protection element showed an important corrosion rate reduction in both elements. The lowest corrosion rate was obtained for HR224 (0.27 $\mathrm{mm} / \mathrm{y}$ ), nevertheless, the internal oxidation detected by SEM (Figure 5), could be a potential issue during thermal cycles, generating mechanic failures, during CSP plant operations and some additional tests will be carried out in future research.

\section{Conclusions}

A new cathodic protection element to control the corrosive potential in chloride molten salts as a thermal energy storage material for CSP plants was analyzed in the paper. Key conclusions include the following:

1. By adding $\mathrm{Al}$ metal into chloride molten salts (cathodic protection), the reduction potential of the alloy can be controlled. The most thermodynamically stable form of chromium in the alloys tested is hence the metallic chromium, meaning that selective oxidation of chromium in the Cr-containing alloys did not occur.

2. This behavior can be explained by the formation of $\mathrm{Al}_{2} \mathrm{O}_{3}$ in the alloy surface which can generate a passivation layer and hence a reduction of the electrolysis current and lower corrosion rates.

This behavior can be a successful starting point to continue with corrosion mitigation strategies focused on cathodic protection using aluminum metal to achieve a CSP plant lifetime of 30 years or longer.

Author Contributions: Conceptualization, A.G.F. and L.F.C.; methodology, A.G.F. and L.F.C.; lab testing, A.G.F.; software, A.G.F.; formal analysis, A.G.F., and L.F.C.; investigation, A.G.F. and L.F.C.; writing-original draft preparation, A.G.F.; writing-review and editing, L.F.C.; supervision, L.F.C.; project administration, A.G.F. and L.F.C.; funding acquisition, A.G.F. and L.F.C. All authors have read and agreed to the published version of the manuscript.

Funding: This project has received funding from the European Union's Horizon 2020 research and innovation program under the Marie Sklodowska-Curie grant No 712949 (TECNIOspring PLUS) and from the Agency for Business Competitiveness of the Government of Catalonia. This work was partially funded by the Ministerio de Ciencia, Innovación y Universidades de España (RTI2018-093849-B-C31 - MCIU/AEI/FEDER, UE). This work was partially funded by the Ministerio de Ciencia, Innovación y Universidades - AgencHia Estatal de Investigación (AEI, RED2018-102431-T). This work is partially supported by ICREA under the ICREA Academia program.

Acknowledgments: The authors would like to thank the Catalan Government for the quality accreditation given to their research group (GREiA 2017 SGR 1537). GREiA is certified agent TECNIO in the category of technology developers from the Government of Catalonia.

Conflicts of Interest: The authors declare no conflicts of interest. The funders had no role in the design of the study; in the collection, analyses, or interpretation of data; in the writing of the manuscript, or in the decision to publish the results. 


\section{References}

1. Mehos, M.; Turchi, C.; Vidal, J.; Wagner, M.; Ma, Z.; Ho, C.; Kolb, W.; Andraka, C.; Kruizenga, A. Concentrating Solar Power Gen3 Demonstration Roadmap; Technical Report; NREL: Golden, CO, USA, 2017.

2. Ding, W.; Gomez-Vidal, J.; Bonk, A.; Bauer, T. Molten chloride salts for next generation CSP plants: Electrolytical salt purification for reducing corrosive impurity level. Sol. Energy Mater. Sol. Cells 2019, 199, 8-15. [CrossRef]

3. Mehrabadi, B.A.T.; Weidner, J.W.; Garcia-Diaz, B.; Martinez-Rodriguez, M.; Olson, L.; Shimpalee, S. Modeling the Effect of Cathodic Protection on Superalloys Inside High Temperature Molten Salt Systems. J. Electrochem. Soc. 2017, 164, C171-C179. [CrossRef]

4. Wang, Y.; Liu, H.; Yu, G.; Hou, J.; Zeng, C. Electrochemical Study of the Corrosion of a Ni-based Alloy GH3535 in Molten (Li,Na,K)F at $700^{\circ} \mathrm{C}$. J. Fluor. Chem. 2015, 178, 14-22. [CrossRef]

5. Wang, Y.; Liu, H.; Zeng, C. Galvanic Corrosion of Pure Metals in Molten Fluorides. J. Fluor. Chem. 2014, 165, 1-6. [CrossRef]

6. Ding, W.; Shi, H.; Xiu, Y.; Bonk, A.; Weisenburger, A.; Jianu, A.; Bauer, T. Molten chloride salts for next generation concentrated solar power plants: Mitigation strategies against corrosion of structural materials. Sol. Energy Mater. Sol. Cells 2018, 184, 22-30. [CrossRef]

7. Krumpelt, M.; Fischer, J.; Johnson, I. The Reaction of Magnesium Metal with Magnesium Chloride. J. Phys. Chem. 1968, 72, 506-511. [CrossRef]

8. Mehrabadi, B.; Weidner, J.W.; Garcia-Diaz, B.; Martinez-Rodriguez, M.; Olson, L.; Shimpalee, S. Multidimensional Modeling of Nickel Alloy Corrosion inside High Temperature Molten Salt Systems. J. Electrochem. Soc. 2016, 163, C830-C838. [CrossRef]

9. Ding, W.; Bonk, A.; Bauer, T. Corrosion behavior of metallic alloys in molten chloride salts for thermal energy storage in concentrated solar power plants: A review. Front. Chem. Sci. Eng. 2018, 12, 564-576. [CrossRef]

10. Fernandez, A.G.; Cabeza, L.F. Corrosion evaluation of eutectic chloride molten salt for new generation of CSP plants. Part 1: Thermal treatment assessment. J. Energy Storage 2020, 27, 101125. [CrossRef]

11. Kisza, A. The capacitance of the diffuse layer of electric double layer of electrodes in molten salts. Electrochim. Acta 2006, 51, 2315-2321. [CrossRef]

12. Orazem, M.E. An integrated approach to electrochemical impedance spectroscopy. Electrochim. Acta 2008, 53, 7360-7366. [CrossRef]

13. Zeng, C.L.; Wang, W.; Wu, W.T. Electrochemical impedance models for molten salt corrosion. Corros. Sci. 2001, 43, 787-801. [CrossRef]

14. Fernandez, A.G.; Cabeza, L.F. Anodic protection assessment using alumina forming alloys in chloride molten salt for CSP plants. Coatings 2020, 10, 138. [CrossRef]

15. Fernández, A.G.; Cabeza, L.F. Corrosion evaluation of eutectic chloride molten salt for new generation of CSP plants. Part 2: Materials screening performance. J. Energy Storage 2020, 29, 101381. [CrossRef]

16. Fernandez, A.G.; Muñoz-Sanchez, B.; Maestre, J.N. Garcia-Romero, High temperature corrosion behavior on molten nitrate salt based nanofluid for CSP plants. Renew. Energy 2019, 130, 902-909. [CrossRef]

17. Zhao, Y.; Klammer, N.; Gomez-Vidal, J. Purification strategy and effect of impurities on corrosivity of dehydrated carnallite for thermal solar applications. RSC Adv. 2019, 9, 41664-41671. [CrossRef]

18. Klammer, N.; Engtrakul, C.; Zhao, Y.; Wu, Y.; Vidal, J. A method to determine $\mathrm{MgO}$ and $\mathrm{MgOHCl}$ in chloride molten salts. Anal. Chem. 2020, 92, 3598-3604. [CrossRef] [PubMed]

19. Choi, S.; Orabona, N.E.; Dale, O.R.; Okabe, P.; Inman, C.; Simpson, M.F. Effect of Mg dissolution on cyclic voltammetry and open circuit potentiometry of molten $\mathrm{MgCl}_{2}-\mathrm{KCl}-\mathrm{NaCl}$ candidate heat transfer fluid for concentrating solar power. Sol. Energy Mater. Sol. Cells 2019, 202, 110087. [CrossRef]

20. Ding, W.; Bonk, A.; Gussone, J.; Bauer, T. Electrochemical measurement of corrosive impurities in molten chlorides for thermal energy storage. J. Energy Storage 2020, 15, 408-414. [CrossRef]

(C) 2020 by the authors. Licensee MDPI, Basel, Switzerland. This article is an open access article distributed under the terms and conditions of the Creative Commons Attribution (CC BY) license (http://creativecommons.org/licenses/by/4.0/). 